\title{
EFEKTIVITAS PEMBERIAN REBUSAN DAUN PANDAN WANGI (Pandanus amaryllifolius Roxb.) TERHADAP PENURUNAN KADAR GLUKOSA DARAH MENCIT (Mus musculus)
}

\author{
Effectiveness Of The Provision Of Fragrant Pandanus Leaf Decoction \\ (Pandanus amaryllifolius Roxb.) On The Decrease In Blood Glucose Levels Of Mice (Mus musculus)
}

\author{
Amran Nur ${ }^{1}$, Desi Reski Fajar ${ }^{2}$, Musdalifah ${ }^{3}$ \\ ${ }^{l}$ Bagian Farmasi, Prodi DIII Farmasi Stikes Pelamonia Kesdam VII/WRB \\ (Email: amrannur70@gmail.com) \\ ${ }^{2}$ Bagian Farmasi, Prodi DIII Farmasi Stikes Pelamonia Kesdam VII/WRB \\ (Email: desi.rf1991@gmail.com) \\ ${ }^{3}$ Bagian Farmasi, Prodi DIII Farmasi Stikes Pelamonia Kesdam VII/WRB \\ (Email:_dalifamusdalifah51@gmail.com)
}

\author{
Alamat Korespondensi: \\ Musdalifah, A.Md. Farm \\ Prodi DIII Farmasi \\ Stikes Pelamonia Kesdam VII/WRB \\ Makassar, 90245 \\ HP: 085824487466 \\ Email: dalifamusdalifah51@gmail.com
}

https://doi.org/10.32382/mf.v14i2.596

\begin{abstract}
ABSTRACK
This study aims to determine the effectiveness of reducing blood glucose levels from decoction of fragrant pandan leaves (Pandanus amaryllifolius Roxb.) In glucose-induced $20 \% \mathrm{~m} / \mathrm{v}$ mice. This study was divided into 5 treatment groups, group I negative control with $0.5 \%$ b / v Na-CMC administration, group II administration of $0.002 \% \mathrm{~b} / \mathrm{v}$ glibenclamide as a positive control, group III administration of fragrant pandan leaves with a concentration of $5 \% b / v$, group IV was given a decoction of fragrant pandan leaves with a concentration of $10 \% \mathrm{~b} / \mathrm{v}$, and group $V$ was given a decoction of fragrant pandan leaves with a concentration of $20 \% \mathrm{~b} / \mathrm{v}$.

Based on the results of statistical research and data analysis, it can be concluded that the decoction of fragrant pandan leaves used with a concentration of $5 \% \mathrm{~b} / \mathrm{v}, 10 \% \mathrm{~b} / \mathrm{v}$, and $20 \% \mathrm{~b} / \mathrm{v}$ can reduce blood glucose levels in mice but the decrease was not significant. because the results of the decrease in fragrant pandan leaf decoction used with this concentration were not much different from the decrease in NaCMC as a negative control.
\end{abstract}

Keywords : Fragrant pandan leaves (Pandanus amaryllifolius Roxb.), decoction, blood glucose, and mice (Mus musculus).

\footnotetext{
ABSTRAK

Penelitian ini bertujuan untuk mengetahui efektivitas penurunan kadar glukosa darah dari rebusan daun pandan wangi (Pandanus amaryllifolius Roxb.) pada mencit yang telah di induksi glukosa $20 \%$ b/v. Penelitian ini dibagi menjadi 5 kelompok perlakuan, kelompok I kontrol negatif dengan pemberian NaCMC $0,5 \% \mathrm{~b} / \mathrm{v}$, kelompok II pemberian glibenklamid $0,002 \% \mathrm{~b} / \mathrm{v}$ sebagai kontrol positif, kelompok III pemberian rebusan daun pandan wangi dengan konsentrasi $5 \% \mathrm{~b} / \mathrm{v}$, kelompok IV pemberian rebusan daun pandan wangi dengan konsentrasi $10 \% \mathrm{~b} / \mathrm{v}$, dan kelompok $\mathrm{V}$ pemberian rebusan daun pandan wangi dengan konsentrasi $20 \% \mathrm{~b} / \mathrm{v}$.

Berdasarkan hasil penelitian dan analisis data secara statistik, maka dapat disimpulkan bahwa rebusan daun pandan wangi yang digunakan dengan konsentrasi $5 \% \mathrm{~b} / \mathrm{v}, 10 \% \mathrm{~b} / \mathrm{v}$, dan $20 \% \mathrm{~b} / \mathrm{v}$ dapat
} 
menurunkan kadar glukosa darah pada mencit tetapi penurunannya tidak signifikan karena hasil penurunan rebusan daun pandan wangi yang digunakan dengan konsentrasi tersebut tidak jauh berbeda dengan penurunan Na-CMC sebagai kontrol negatif.

Kata kunci : Daun pandan wangi (Pandanus amaryllifolius Roxb.), rebusan, glukosa darah, dan mencit (Mus musculus).

\section{PENDAHULUAN}

Diabetes melitus adalah gangguan metabolit yang ditandai dengan peningkatan kadar glukosa dalam darah (hiperglikemia). Hal ini dihubungkan dengan keadaan abnormalitas metabolisme karbohidrat, lemak dan protein terjadi karena kelainan sekresi insulin, kerja insulin (sensitivitas) atau keduanya, dari faktor genetik serta faktor lingkungan dan mengakibatkan komplikasi kronis termasuk mikrovaskular, makrovaskular dan neuropatik kronis (Dipro et al, 2015; Hasan et al, 2013).

Diabetes melitus mempunyai gejala seperti banyak makan (polifag), banyak minum (polidipsi), dan banyak kencing (poliuri). Penderita diabetes mengetahui dirinya mengidap diabetes setelah terjadi komplikasi progresif seperti gangguan kardiovaskular, musculoskeletal dan intregumen yang akhirnya dapat menyebabkan kematian. Komplikasi ini biasa dicegah jika penderita mau melakukan tatalaksana perubahan pola makan, edukasi, olahraga, dan terapi farmakologi (Nurrahmani \& Kurniadi, 2014).

Penanganan kuratif penyakit diabetes mellitus terlebih dahulu dilakukan secara non farmakologis

yaitu dengan diet dan olah raga untuk mencapai target glukosa darah yang diinginkan. Bila kedua cara non farmakologi belum mampu mencapai target glukosa darah yang diinginkan maka tindakan kuratif diabetes melitus dapat dibantu dengan pengobatan farmakologi tetapi tergantung pada tipe diabetes mellitusnya (Nurrahmani, 2011).

Salah satu obat tradisional yang banyak digunakan masyarakat Indonesia secara turun temurun khususnya masyarakat Galesong, Kabupaten Takalar, Sulawesi Selatan adalah daun pandan wangi (Pandanus amaryllifolius Roxb). Tanaman ini merupakan jenis tanaman tropis yang umum terdapat di dunia dan digunakan sebagai obat anti diabetes (Ong, 2008).

Daun pandan wangi (Pandanus amaryllifolius Roxb.) memiliki kandungan alkaloid, saponin, dan flavonoid. (Dalimartha, 2009). Tanin mencegah timbunan glukosa dan lemak darah (Dalimartha, 2005). Alkaloid akan menurunkan kebutuhan insulin dan kadar glukosa darah (Bunting et al., 2006). Flavonoid akan menghambat GLUT 2 mukosa usus yang menyebabkan kadar glukosa darah akan turun (Song et al., 2002).

\section{METODE}

Penelitian ini merupakan jenis penelitian eksperimen laboratorium, yaitu untuk mengetahui efektivitas penurunan kadar glukosa darah dari rebusan daun pandan wangi (Pandanus amaryllifolius Roxb.) konsentrasi $5 \%, 10 \%$ dan $20 \%$ terhadap hewan uji mencit jantan, Na-CMC $0,5 \%$ sebagai kontrol negatif dan suspensi glibenklamid $5 \mathrm{mg}$ sebagai kontrol positif.

\section{Tempat dan waktu penelitian}

Penelitian ini di laksanakan di Laboratorium Farmasi Stikes Pelamonia Kesdam XIV/Hasanuddin. Waktu penelitian pada bulan Juli 2018.

\section{Bahan uji}

Daun pandan wangi (Pandanus amaryllifolius Roxb.) sebanyak 50 gram.

\section{Sampel}

Mencit (Mus musculus) yang digunakan adalah 15 ekor.

a. Kriteria inklusi

1). Berkelamin jantan

2). Berat badan 20-30 g

b. Kriteria eksklusi

1). Berkelamin betina

2). Berat badan dibawah $20 \mathrm{~g}$

\section{Variabel penelitian}

Variabel bebas dalam penelitian ini adalah kandungan kimia daun pandan wangi (Pandanus amaryllifolius Roxb.) adalah alkaloid, saponin, flavonoid (Dalimartha, 2009) dan tannin (Dalimartha, 2005). Sedangkan variabel terikat adalah kadar glukosa darah mencit jantan yang diinduksi glukosa.

\section{Definisi operasional}

Efektivitas dalam penelitian ini adalah kemampuan daun pandan wangi (Pandanus amaryllifolius Roxb.) untuk menurunkan kadar glukosa darah pada mencit (Mus musculus) dengan konsentrasi yang digunakan yaitu 5\% 
$\mathrm{b} / \mathrm{v}, 10 \% \mathrm{~b} / \mathrm{v}, 20 \% \mathrm{~b} / \mathrm{v}$ mampu menurunkan kadar glukosa darah mencit (Mus musculus).

\begin{abstract}
Alat dan bahan
Alat yang digunakan adalah gelas ukur (Iwaki), gelas kimia (Pyrex), glukometer (NESCO ${ }^{\circledR}$ MultiCheck ${ }^{\circledR}$ Model : N-01). Sedangkan bahan yang digunakan adalah rebusan daun pandan wangi, $\mathrm{Na}-\mathrm{CMC}$, suspensi glibenklamid, strip glukosa.

\section{Prosedur kerja \\ Pengambilan dan Pengolahan Bahan Uji}

Bahan uji berupa daun pandan wangi segar (Pandanus amaryllifolius Roxb.) yang diambil di Desa Galesong, Kab. Takalar, Kota Makassar, Sulawesi Selatan.
\end{abstract}

\section{Penyiapan Bahan Penelitian}

a. Pembuatan rebusan daun pandan wangi

Rebusan daun pandan wangi dibuat dengan konsentrasi bertingkat 5\%,10\% dan $20 \%$, ditimbang sebanyak 5 gram dimasukkan ke dalam gelas kimia dan dibasahi dengan air sebanyak $200 \mathrm{ml}$, direbus hingga tersisa sebanyak $100 \mathrm{ml}$. Perebusan dilakukan di atas kompor dengan suhu $100^{\circ} \mathrm{C}$ selama 20 menit (rebusan daun pandan wangi dengan konsentrasi 5\%). Dilakukan hal yang sama untuk rebusan dengan konsentrasi $10 \%$ dan $20 \%$ dengan berat bahan uji yang berbeda.

b. Pembuatan suspensi Na-CMC 0,5\% b/v

Suspensi Na-CMC dibuat dengan cara memanaskan air suling sebanyak $50 \mathrm{ml}$ hingga $70^{\circ} \mathrm{C}$ lalu dimasukkan Na-CMC sebanyak 0,5 gram dimasukkan sedikit demi sedikit dan diaduk dengan menggunakan pengaduk hingga terbentuk larutan homogen. Volumenya dicukupkan dengan air panas hingga $100 \mathrm{ml}$.

c. Pembuatan suspensi glibenklamid

Sebanyak 10 tablet glibenklamid ditimbang kemudian dihitung bobot ratarata tiap tablet. Serbuk tablet glibenklamid ditimbang 78,39 mg glibenklamid kemudian ditambahkan larutan Na-CMC $0,5 \mathrm{~b} / \mathrm{v}$, sedikit demi sedikit sambil diaduk hingga homogen. Dicukupkan volumenya dengan larutan Na-CMC $0,5 \%$ b/v hingga $100 \mathrm{ml}$.

d. Pembuatan larutan glukosa $20 \% \mathrm{~b} / \mathrm{v}$ Sebanyak 20 gram glukosa dimasukkan ke dalam labu ukur $100 \mathrm{ml}$ lalu ditambahkan air suling sebanyak $50 \mathrm{ml}$, di kocok hingga larut kemudian dicukupkan volumenya hingga $100 \mathrm{ml}$. e. Pemilihan dan penyiapan hewan uji

Hewan uji yang digunakan dalam penelitian ini adalah mencit (Mus musculus) jantan, berbadan sehat dengan bobot 20-30 gram. Jumlah mencit yang digunakan adalah 15 ekor dibagi 5 kelompok dan masing-masing kelompok terdiri dari 3 ekor.

f. Perlakuan terhadap hewan uji

Sebelum perlakuan, diambil darah awal mencit kemudian ditimbang dan dipuasakan 3-4 jam, dan diberi larutan glukosa kemudian diambil darah kedua. Selanjutnya kelompok 1 diberi $\mathrm{Na}$-cmc sebagai kontrol negatif, kelompok 2 diberi suspensi glibenklamid sebagai pembanding dan kelompok 3-5 diberi rebusan daun pandan wangi secara oral sesuai bobot mencit (1 $\mathrm{ml} / 20 \mathrm{~g} \mathrm{BB}$ ) dengan konsentrasi 5\%, 10\%, $20 \%$ sebagai kelompok uji.

g. Penentuan kadar glukosa darah

Sebelum pengambilan darah terlebih dahulu glukometer diaktifkan kemudian strip dimasukkan ke dalam glukometer. Darah diambil melalui pembuluh darah vena pada ujung ekor kemudian diteteskan pada strip glukometer. Tetesan darah yang mengandung glukosa dan beraksi dengan zat tertentu yang terkandung dalam strip (glukosa oksidase) kemudian secara otomatis dalam waktu 10 detik kadar glukosa darah akan terukur dan hasilnya dapat dibaca monitor glukometer.

h. Pengamatan dan pengumpulan data

Pengamatan dilakukan terhadap mencit setelah diberi perlakuan dan pengumpulan data diambil berdasarkan hasil

\section{Cara pengolahan dan analisis data}

Pengolahan data digunakan bantuan program komputer SPSS (Statistical Product and Service) tipe 23 Statistics Descriptives.

\section{HASIL}

Dari penelitian yang telah dilakukan terhadap efektivitas pemberian rebusan daun pandan wangi terhadap penurunan kadar glukosa darah mencit, diperoleh hasil seperti tabel 1.

\section{PEMBAHASAN}

Penelitian dengan judul efektivitas pemberian rebusan daun pandan wangi (Pandanus amaryllifolius Roxb.) terhadap penurunan kadar glukosa darah mencit ini dilakukan dengan tujuan untuk mengetahui apakah rebusan daun pandan wangi mampu menurunkan kadar glukosa darah. Pada 
penelitian ini dilakukan rebusan daun pandan wangi dengan konsentrasi $5 \%$ b/v, $10 \%$ b/v, $20 \%$ b/v, karena masyarakat khususnya di Galesong, Kab. Takalar masyarakat merebus daun pandan wangi sebanyak 5 gram dalam 2 gelas air menjadi 1 gelas air ketika sesudah direbus, maka dari itu saya memilih konsentrasi $10 \% \mathrm{~b} / \mathrm{v}$ dan $20 \% \mathrm{~b} / \mathrm{v}$ untuk membandingkan apakah dengan konsentrasi tersebut dengan bertambah banyaknya daun pandan wangi yang akan direbus lebih mampu menurunkan kadar glukosa darah, juga digunakan Na-CMC 0,5\% $\mathrm{b} / \mathrm{v}$ sebagai kontrol negatif dan suspensi glibenklamid $0.002 \% \quad \mathrm{~b} / \mathrm{v}$ sebagai kontrol positif.

Sebagai kontrol positif digunakan glibenklamid yang merupakan obat anti diabetik oral golongan sulfonilurea generasi kedua. Glibenklamid memiliki efek hipoglikemik yang kuat dengan dosis yang rendah. Glibenklamid dibuat dalam bentuk sediaan suspensi yaitu dengan $\mathrm{Na}-\mathrm{CMC} 0,5 \% \mathrm{~b} / \mathrm{v}$ karena sifatnya yang praktis tidak larut dalam air. Na-CMC digunakan sebagia kontrol negatif agar potensi penurunan kadar glukosa darah oleh sampel dapat terlihat lebih jelas.

Penurunan efektivitas kadar glukosa darah dilakukan secara enzimatik dengan menggunakan metode toleransi glukosa oral, dimana glukosa di oksidasi oleh oksigen menjadi asam glukonat dan hidrogen peroksida. Reaksi ini dikatalasi oleh enzim glukosa oksidase. Darah diambil melalui pembuluh darah vena pada ujung ekor kemudian diteteskan pada strip glukometer. Tetesan darah yang mengandung glukosa akan bereaksi dengan zat tertentu yang terkandung pada strip (glukosa oksidase) kemudian secara otomatis dalam waktu 10 detik kadar glukosa akan terukur dan hasilnya dapat di baca pada monitor glukometer.

Hewan uji yang digunakan adalah mencit jantan karena mencit jantan memiliki sistem hormonal yang lebih stabil dibandingkan mencit betina yang mana memiliki kadar glukosa darah lebih tinggi pada saat hamil sebab terjadi peningkatan hormon meliputi laktogen plasenta, kartisol, prolactin, dan progesterone. Selain itu kebutuhan nutrisi pada saat hamil meningkat sehingga glukosa yang di hasilkan lebih banyak dibandingkan saat tidak hamil sehingga dapat mempengaruhi hasil penelitian. Sebelum perlakuan dilakukan tes glukosa awal terhadap mencit setelah itu mencit di puasakan untuk meniadakan pengaruh biologis dari hewan uji yang tidak dapat dihilangkan sehingga relative dapat mempengaruhi hasil yang di peroleh.
Untuk menginduksi glukosa darah mencit, digunakan larutan glukosa $20 \%$ b/v yang diberikan pada mencit 1 jam sebelum pemberian sediaan uji yang bertujuan menaikan kadar gula glukosa awal, sehingga kemampuan menurunkan kadar glukosa darah dari sediaan uji dapat diamati.

Dalam penelitian ini, kadar glukosa darah mencit diukur selama 90 menit dengan intravena waktu 30 menit. Hal tersebut karena tubuh memerlukan waktu untuk mengabsorpsi glukosa dalam tubuh dan digunakan jangka 90 menit untuk melihat efek penurunan kadar glukosa darah yang lebih jelas setelah pemberian rebusan daun pandan wangi.

Berdasarkan hasil penelitian yang diperoleh (Tabel 1) terlihat bahwa tabel kelompok mencit yang diberi Na-CMC sebagai kontrol negatif terjadi penurunan kadar glukosa darah, pemberian rebusan daun pandan wangi dengan konsentrasi 5\%, $10 \%$ dan $20 \%$ b/v terjadi penurunan kadar glukosa darah yang tidak jauh berbeda dengan pemberian Na-CMC atau penurunannya tidak signifikan, sedangkan pemberian suspensi glibenklamid 0,002\% b/v menunjukkan penurunan kadar glukosa.

Dari hasil pengolahan data SPSS (Statistical Product and Service) menunjukkan bahwa data yang diperoleh pada menit 30, 60, 90 pemberian $\mathrm{Na}-\mathrm{CMC} \quad 0,5 \%$ b/v sebagai kontrol negatif dan pemberian glibenklamid $0,002 \% \mathrm{~b} / \mathrm{v}$ sebagai kontrol positif setelah analisis statistik data hasil penurunan kadar glukosa darah mencit dinyatakan signifikan, sedangkan pada pemberian rebusan daun pandan wangi dengan konsentrasi $5 \%$ b/v, $10 \%$ $\mathrm{b} / \mathrm{v}$ dan $20 \% \mathrm{~b} / \mathrm{v}$ tetap memberikan efek penurunan gula darah pada mencit tapi dari hasil analisis statistik tidak terlalu signifikan penurunan gula darahnya.

Dari hasil analisis statistik dapat diterima dikarenakan ada faktor yang dapat mempengaruhi hasil dari pengujian tersebut yaitu kondisi dari hewan coba bila dalam satu kelompok mencit terdapat hewan coba yang tidak sensitif pada pemberian rebusan daun pandan wangi maka akan mempengaruhi data keseluruhan dalam satu kelompok tersebut.

\section{KESIMPULAN}

Berdasarkan hasil dan analisis data secara statistik, maka dapat disimpulkan bahwa rebusan daun pandan wangi yang digunakan dengan konsentrasi $5 \%$ b/v, $10 \%$ b/v dan $20 \%$ $\mathrm{b} / \mathrm{v}$ dapat menurunkan kadar glukosa darah tetapi penurunannya tidak signifikan karena hasil penurunan rebusan daun pandan wangi yang digunakan dengan konsentrasi tersebut 
tidak jauh berbeda dengan penurunan $\mathrm{Na}-\mathrm{CMC}$ sebagai kontrol negatif.

\section{SARAN}

Perlu diteliti lebih jelas tentang senyawa dari daun pandan wangi yang berfungsi dalam penurunan kadar glukosa darah. Penelitian selanjutnya menggunakan ekstrak non polar daun pandan wangi untuk menurunkan kadar glukosa darah.

\section{DAFTAR PUSTAKA}

Bunting K., Wang J.K and Shannan M.F,. 2006. Control of Interleukin-2-gene Transcription: a Paradigm For Inducible, Tissue Specifik Gene Expression, Interleukins, eds. G. Litwack, 74: Elsevier Academic Press Inc., pp. 105-145

Dalimartha S. 2005. Ramuan Tradisional Untuk Pengobatan Diabetes Mellitus, Penebar Swadaya, Bogor.

Dalimartha S. 2009. Atlas Tumbuhan Obat Indonesia, Pustaka Bunda, Jakarta.

Dipro J., Talbe R.L., Yee G.C., Matzke G.R., Wells B.G., and Posey L.M., 2015. Pharmakotherapy: A Patophysiologic Approach, 9th Edition. Mc Graw Hill, New York.

Hasan M., Khan M.I., Umar B.U., and Sadeque M. 2013. Comparative study of the Effect of Ethanolic Extra of Swietenia mahagoni Seeds with rosiglitazone on Experimentally Induced Diabetes Melitus in Rats. Faridpur Med. Coll. J. No. 39, p. 6-10.

Nurrahmani U., \& Kurniadi H. 2014. Stop! Gejala penyakit jantung koroner, kolestrol tinggi, diabetes melitus, hipertensi. Yogyakarta: Istana Media.

Nurrahmani U. 2011. Stop Diabetes. Yogyakarta: Familia.

Song J., Kwon O., Chen S., Daruwala R., Eck P., Park J. B., and Levine M., 2002. Flavonoid Inhibition of SVCTI and GLUT2, Intestinal transporterts for vitamin $\mathrm{C}$ and glucose, J. Biol Chem. 
Tabel 1.

\begin{tabular}{|c|c|c|c|c|c|c|}
\hline \multirow[t]{2}{*}{ Kelompok } & \multirow[t]{2}{*}{ Mencit } & \multirow[t]{2}{*}{$\begin{array}{l}\text { Sebelum } \\
\text { induksi } \\
\text { glukosa } \\
\text { (mg/dL) } \\
\end{array}$} & \multirow[t]{2}{*}{$\begin{array}{l}\text { Setelah } \\
\text { induksi } \\
\text { glukosa } \\
\text { (mg/dL) }\end{array}$} & \multicolumn{3}{|c|}{$\begin{array}{l}\text { Induksi Glibenklamid, Na-CMC, } \\
\text { dan rebusan daun pandan wangi }\end{array}$} \\
\hline & & & & $30^{\prime}$ & $60^{\prime}$ & $90^{\prime}$ \\
\hline \multirow{3}{*}{$\mathrm{Na}-\mathrm{CMC} 0,5 \%$} & I & 113 & 121 & 96 & 74 & 85 \\
\hline & II & 110 & 189 & 81 & 76 & 80 \\
\hline & III & 134 & 78 & 106 & 88 & 97 \\
\hline \multirow{3}{*}{$\begin{array}{c}\text { Glibenklamid } \\
0,002 \%\end{array}$} & I & 110 & 121 & 46 & 46 & 51 \\
\hline & II & 119 & 167 & 34 & 45 & 47 \\
\hline & III & 126 & 128 & 58 & 50 & 59 \\
\hline \multirow{3}{*}{ Rebusan 5\% } & I & $\begin{array}{l}90 \\
\end{array}$ & 163 & 83 & 64 & 73 \\
\hline & II & 115 & 125 & 52 & 77 & 69 \\
\hline & III & 108 & 134 & 90 & 98 & 98 \\
\hline \multirow{3}{*}{ Rebusan $10 \%$} & I & 96 & 119 & 108 & 99 & 108 \\
\hline & II & 59 & 138 & 93 & 87 & 92 \\
\hline & III & 47 & 95 & 70 & 59 & 69 \\
\hline \multirow{3}{*}{ Rebusan 20\% } & $T$ & 108 & 189 & 83 & 77 & 82 \\
\hline & II & 128 & 152 & 70 & 63 & 71 \\
\hline & III & 125 & 138 & 74 & 85 & 69 \\
\hline
\end{tabular}




\section{MEDIA FARMASI}

POLITEKNIK KESEHATAN MAKASSAR

Penasehat

Penanggung Jawab

Dewan Redaksi

Ketua

Anggota

Mitra Bestari

Alamat Redaksi
: Direktur Politeknik Kesehatan Kemenkes Makassar

: Ketua Jurusan Farmasi Politeknik Kesehatan

Kemenkes Makassar

: $\quad$ Santi Sinala, S,Si, M.Si, Apt

: Hendra Stevani, S.Si, M.Kes, Apt

Sisilia Teresia Rosmala Dewi, S.Si, M.Kes, Apt

Muli Sukmawaty, S.Farm, Apt

Muhammad Riswan, S.Kom

: $\quad$ Dr. Islamudin Ahmad, M.Si,Apt (Universitas Mulawarman)

DR. Rusli, Sp.FRS, Apt

DR. Hj. Nurisyah, M.Si, Apt (Poltekkes Makassar)

DR. Sesilia Rante Pakadang, M.Si, Apt (Poltekkes Makassar)

DR. H. Asyhari Asyikin, S.Farm, M.Kes (Poltekkes Makassar)

: Jurusan Farmasi

Politeknik Kesehatan Kementerian Kesehatan Makassar

J1. Baji Gau No.10 Makassar

Telp. 0411-854021, 830883 Fax. 0411-830883

Kode pos 90134

Website :

http://journal.poltekkes-mks.ac.id/ojs2/index.php/mediafarmasi/index 


\section{EDITORIAL}

Pembaca yang budiman, ucapan syukur Alhamdulillah kami panjatkan ke hadirat Tuhan Yang Maha Kuasa karena berkat rahmat dan anugerahNya sehingga penerbitan Vol. XIV No.2, Oktober 2018 MEDIA FARMASI POLITEKNIK KESEHATAN MAKASSAR dapat terlaksana dan telah mendapat legalitas sebagai media resmi dari Lembaga Ilmu Pengetahuan Indonesia (LIPI) dengan nomor penerbitan pISSN No. 0216-2083 dan e-ISSN No. 2622-0962.

Media Farmasi Politeknik Kesehatan Makassar merupakan suatu wadah dalam menampung aspirasi ilmiah sehingga dapat menggugah motivasi dan inovasi dari dosen di lingkup Jurusan Farmasi Politeknik Kesehatan Makassar serta artikel dari simpatisan untuk melakukan kajian ilmiah.

Media Farmasi Politeknik Kesehatan Makassar diterbitkan 2 kali dalam setahun yaitu pada bulan April dan Oktober. Sebagai majalah ilmiah, Media Farmasi mengembangkan misi dalam memajukan ilmu pengetahuan dan teknologi kesehatan khususnya di bidang farmasi

Akhirnya redaksi sangat berharap bahwa semua artikel yang disajikan dalam edisi ini dapat memberi apresiasi keilmuan di bidang kesehatan bagi kita semua. Oleh karena itu kritikan dan saran sangat kami harapkan demi kesempurnaan edisi-edisi selanjutnya.

Selamat membaca

Makassar, Oktober 2018

Redaksi 


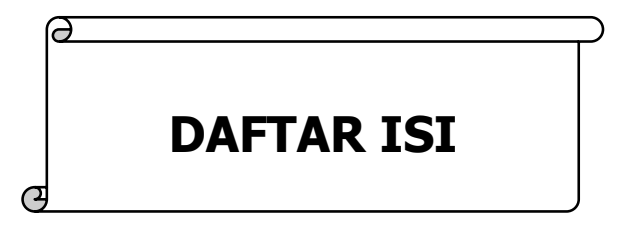

Pengaruh Pemberian Ekstrak Etanol Daun Afrika (Vernonia amygdalina

Del.) terhadap Kadar Asam Urat Darah Mencit Jantan (Mus musculus)

Jumain, Asmawati, Rini Karnita

Efektivitas Pemberian Rebusan Daun Pandan Wangi (Pandanus

Amaryllifolius Roxb.) terhadap Penurunan Kadar Glukosa Darah

Mencit (Mus musculus)

Amran Nur, Desi Reski Fajar, Musdalifah

Uji Efek Analgetik Infusa Jahe (Zingiber officinale Roscoe) terhadap Hewan Uji Mencit Jantan (Mus musculus)

Sisilia T. Rosmala Dewi, Hiany Salim.

Pengaruh Usia dan Tingkat Pendidikan terhadap Pemahaman Pasien

Setelah Pelayanan Informasi Obat di Puskesmas Makale Kabupaten

Tana Toraja Tahun 2018

Estherina Allo Payung, Septyani Mambela

Uji Daya Hambat Antibiotika Terhadap Bakteri Penyebab Infeksi

Saluran Kemih Di Rumah Sakit Salewangang Maros

Andi Dian Aulia Saudi, Rusdy

Uji Aktivitas Ekstrak Buah Pare (Momordica charantia L) terhadap Pertumbuhan Propionibacterium acnes

Dwi Rachmawaty Daswi, Asmawati

Analisis Kandungan Merkuri (Hg) pada Sediaan Krim Pemutih yang Beredar di Pasaran Kota Makassar dengan Menggunakan Metode Spektrofotometri Serapan Atom

Dedy Ma'ruf, Andi Asmawati, Ririn Muliana

Penentuan Total Polifenol Ekstrak Etanol Kulit Kecapi (Sandoricum koetjape) dari Lamasi Kabupaten Luwu

Santi Sinala, Minati, Alfrida Monica Salasa

Uji Potensi Antimikroba Hasil Fraksinasi Ekstrak Daun Kecombrang (Etlingera elatior) terhadap Candida albicans Penyebab Keputihan Pada Ibu Hamil

St. Ratnah, Alfrida Monica Salasa, H. Ismail Ibrahim 
Efek Konseling terhadap Tingkat Pengetahuan Ibu pada Terapi

Diare Balita

Khaerani, Surya Ningsi, Andi Try Resti Fauziah Sahib

Uji Daya Hambat Daun Tammate (Lannea coromandelica) terhadap

Bakteri Propionibacterium acnes dan Escherichia coli

Nurlaela, Abd.Karim, Taufiq Dalming

Efektivitas Ekstrak Air Buah Belimbing Wuluh (Averrhoa bilimbi)

Terhadap Pertumbuhan Propionibacterium acnes

Arisanty, Rara Puspa Dewi

Aktivitas Perasan Biji Pinang (Areca catechu L.) terhadap Pertumbuhan

Streptococcus mutans

Ikke Nurjanna, Hendra Stevani, Ratnasari Dewi

Evaluasi Tingkat Kepuasaan Pasien terhadap Pelayanan Kefarmasin di Depo IGD

Rumah Sakit TK II Pelamonia Makassar

Rahmawati, Desi Reski Fajar, Ira Widya Sari

78

Analisis Lama Waktu Tunggu Pelayanan Resep di Apotek BPJS

Rawat Jalan Rumah Sakit Pelamonia

Veronika Dampung, Ita Purnama Sari, Citra Rahayu, Rusli 